\section{INT7100 IPRO - A soybean cultivar for an extensive growing area in the South and Cerrado in Brazil}

\section{Tamiris Pereira da Silva ${ }^{1^{*}}$, Júlio César DoVale ${ }^{1}$, Lucas Silvérioº Jean Newton Marques ${ }^{3}$, Reginaldo Rosa ${ }^{3}$, Luan Henrique Guarido da Silva ${ }^{3}$, Lucas Willwock ${ }^{3}$, Sâmia Teodoro ${ }^{3}$ and Jaqueline Bueno da Silva ${ }^{4}$}

\begin{abstract}
Soybean cultivars with "plasticity" traits, such as good branching ability, ensure compensation of gaps in planting. The cultivar INT7100 IPRO provides excellent branching ability and plant architecture, facilitating control of pests and diseases, and it contains the biotechnology INTACTA RR2 PRO ${ }^{\circledR}$. It is resistant to stem canker, brown stem rot, and bacterial blight.
\end{abstract}

Keywords: Glycine max, branching, early maturity, disease resistance, glyphosate tolerance.

\section{INTRODUCTION}

Soybean (Glycine max L. Merrill) growing is one of the agricultural activities that has most increased worldwide in recent decades. Brazil has had a prominent position in this expansion, and the area planted to soybean represents approximately $57 \%$ of the area dedicated to grain cultivation in the country. In the $2017 / 2018$ crop season, Brazil produced 119 million tons of soybean, with an average yield of $3394 \mathrm{~kg} \mathrm{ha}^{-1}$ (CONAB 2019).

Currently, in choosing a soybean cultivar, producers observe not only yield, but also the following factors: recommended growing region, maturity group, growth type, average crop cycle, plant height, resistance to lodging, sowing season, and reaction to diseases (Sediyama et al. 2015). Other important characteristics are protection against the main leaf-eating caterpillars and tolerance to glyphosate herbicide, which is currently conferred through insertion of the INTACTA RR2 $\mathrm{PRO}^{\circledR}$ biotechnology (Uarrota et al. 2019).

The development of early-maturity soybean cultivars is the main objective of the soybean breeding program developed by the Centro Universitário Integrado of Campo Mourão, PR, Brazil, to allow the producer to take advantage of a second crop season. The cultivar developed must not only have early maturity, but also good yield potential, which is a characteristic of the cultivar INT7100 IPRO, since its excellent branching allows it to maintain the number of pods and grains per square meter even with gaps in planting.

\section{METHODS}

The soybean cultivar INT7100 IPRO was derived from crossbreeding the
Crop Breeding and Applied Biotechnology 19:3, 360-363, 2019 Brazilian Society of Plant Breeding. Printed in Brazil http://dx.doi.org/10.1590/198470332019v19n3c49

\footnotetext{
*Corresponding author: E-mail: tamirisjua@gmail.com (iD) ORCID: 0000-0002-8356-0809
}

Received: 09 August 2018 Accepted: 17 April 2019

${ }^{1}$ Universidade Federal do Ceará, Departamento de Fitotecnia, Av. Mister Hull, 2977, Campus do Pici, 60.356-000, Fortaleza, CE, Brazil

${ }^{2}$ Centro Universitário Integrado, 87.300-970, Campo Mourão, PR, Brazil ${ }^{3}$ INT Sementes de Soja, 87.300-970, Campo Mourão, PR, Brazil

${ }^{4}$ Universidade Estadual de Maringá, Departamento de Genética e Melhoramento, Campus Universitário, 87.020-900, Maringá, PR, Brazil 
elite inbred lines INT19372 and INT19360 in the Genetic Improvement Program of the Centro Universitário Integrado (CEI) in Campo Mourão, Paraná, Brazil. After obtaining the $F_{1}$ seeds, the segregating generations proceeded by the SPD (Single Pod Descent) method. The cross that generated the cultivar registered as INT7100 IPRO was called 14/MO60.23 until the end of selection and harvest of the progenies at the experimental station in the 2013/2014 crop season. In the $2014 / 2015$ crop season, it was placed for evaluation in a preliminary test. In the 2015/2016 and 2016/2017 crop seasons, value for cultivation and use (VCU) experiments were performed, following the requirements of the Brazilian Ministry of Agriculture (MAPA), in diverse soil and climatic conditions in soybean macro-regions 1, 2, and 3, in order to expand recommendation of the cultivar for wider and more diverse environments. Genetic seed production started in 2017.

\section{PERFORMANCE CHARACTERISTICS}

Experiments were conducted in the 2015/2016, 2016/2017, and 2017/2018 crop seasons, for a total of 21 environments in the states of Paraná, Goiás, and Mato Grosso do Sul, which were evaluated according to MAPA criteria (Table 1). These environments represent different edaphic and climatic regions and soybean macro-regions. Thus, for each location, a planting density was used that, together with good management, allows the cultivar under testing to obtain good yield from its architectural, branching, and early maturity characteristics (Table 2). After analysis of the data and confirmation of superior performance of INT7100 IPRO compared to the commercial controls recommended for each location, the cultivar was registered for growing.

In the yield evaluations, the cultivar INT7100 IPRO obtained a higher average than all the commercial cultivars used as controls, considering the overall average of the three crop seasons (2015/2016, 2016/2017, and 2017/2018) evaluated in each location (Table 2). The superiority of its performance compared to the controls used in each environment ranged from $3 \%$ to $32 \%$ in relative grain yield. Commercial cultivars with prominent yields for each site were used as checks.

Considering the edaphic and climatic regions (ECRs) used, the mean yield of the cultivar INT7100 IPRO was $4297 \mathrm{~kg}$ $\mathrm{ha}^{-1}$ for ECR 103, 13\% higher than the check M6210 IPRO (3810 kg ha-1) and 7\% higher than DM 6563RSF IPRO (4033 $\left.\mathrm{kg} \mathrm{ha}^{-1}\right)$. For ECR 201, its mean yield was $4441 \mathrm{~kg} \mathrm{ha}^{-1}, 16 \%$ higher than DM 6563RSF IPRO (3831 kg ha-1) and 3\% higher than M6210 IPRO (4313 kg ha-1). In ECR 202, its mean yield was $3599 \mathrm{~kg} \mathrm{ha}^{-1}$, corresponding to a $10 \%$ increase in relative yield compared to BMX POTÊNCIA RR (3281 kg ha-1) and 1\% higher than M6410 IPRO (3561 kg ha-1). Finally, in ECR 301, the cultivar INT7100 IPRO had a mean yield of $3781 \mathrm{~kg} \mathrm{ha}^{-1}, 11 \%$ higher than BMX DESAFIO 8473 RSF RR (3403 kg ha-1) and 9\% higher than BMX POTÊNCIA RR (3473 $\left.\mathrm{kg} \mathrm{ha}^{-1}\right)$.

Adaptability and stability assessments were also made with the yield data from the regions tested. The results indicated that the cultivar INT7100 IPRO was not only higher yielding than the highest yielding cultivars on the market, but also had wide adaptability and stability.

The most appropriate season for sowing is from September 20 to October 30 for locations in the South region and from October 1 to November 5 for locations in Goiás and Mato Grosso. The cultivar requires medium to high fertility soils for all indicated regions. It is classified as early maturity and falls within maturation group 6.4, with a cycle from 118 to 125 days.

Table 1. Municipalities of the experimental trials (LOCATION), state (STATE), soybean macro-region (MR), edaphic and climatic region (ECR), and ideal sowing density (DENSITY) for cultivating INT7100 IPRO

\begin{tabular}{lcccc}
\hline Location & State & MR & ECR & DENSITY \\
\hline Guarapuava & PR & 1 & 103 & 201 \\
Campo Mourão & PR & 2 & 201 & 14 \\
Floresta & PR & 2 & 201 & 16 \\
Luiziana & PR & 2 & 202 & 12 \\
Maracajú & PR & 2 & 301 & 16 \\
Rio Verde & GO & 3 & 301 & 18 \\
Cristalina & GO & 3 & 14 \\
\hline
\end{tabular}


Table 2. Mean yield (MY) and relative yield (RY) of cultivar INT7100 IPRO compared to commercial controls in the 2015/2016, 2016/2017, and 2017/2018 crop seasons in the state of Paraná, Goias, and Mato Grosso do Sul

\begin{tabular}{|c|c|c|c|c|c|c|}
\hline Location & Cultivar & $15 / 16$ & $16 / 17$ & $17 / 18$ & MY $\left(\mathrm{kg} \mathrm{ha}^{-1}\right)$ & RY $(\%)$ \\
\hline & M6210IPRO & 3078 & 4784 & 3568 & 3810 & 100 \\
\hline \multirow[t]{3}{*}{ Guarapuava/PR } & DM 6563RSF IPRO & 3344 & 5175 & 3580 & 4033 & 106 \\
\hline & INT7100 IPRO & 3629 & 4837 & 4425 & 4297 & 113 \\
\hline & M6210IPRO & 3662 & 4034 & 4744 & 4147 & 125 \\
\hline \multirow[t]{2}{*}{ Campo Mourão/PR } & DM 6563RSF IPRO & 2622 & 2290 & 5052 & 3321 & 100 \\
\hline & INT7100 IPRO & 3697 & 3911 & 5522 & 4377 & 132 \\
\hline \multirow{2}{*}{ Floresta/PR } & INT7100 IPRO & 3490 & 5107 & 3785 & 4127 & 109 \\
\hline & M6210IPRO & 4222 & 5366 & 4726 & 4805 & 109 \\
\hline \multirow[t]{3}{*}{ Luiziana/PR } & DM 6563RSF IPRO & 4155 & 4953 & 4014 & 4374 & 100 \\
\hline & INT7100 IPRO & 4653 & 5225 & 4575 & 4818 & 110 \\
\hline & BMX POTÊNCIA RR & 3825 & 4637 & 5192 & 4551 & 100 \\
\hline \multirow[t]{3}{*}{ Rio Verde/GO } & BMX DESAFIO 8473 RSF RR & 2779 & 4125 & 3682 & 3529 & 100 \\
\hline & INT7100 IPRO & 3411 & 4457 & 4087 & 3985 & 113 \\
\hline & BMX POTÊNCIA RR & 1637 & 4142 & 4195 & 3325 & 101 \\
\hline \multirow[t]{2}{*}{ Cristalina/GO } & BMX DESAFIO 8473 RSF RR & 1733 & 4218 & 3881 & 3277 & 100 \\
\hline & INT7100 IPRO & 2220 & 4333 & 4175 & 3576 & 109 \\
\hline
\end{tabular}

The INT7100 IPRO soybean cultivar has indeterminate growth habit, excellent yield, yellow seeds of low luster, light brown hilum, purple flowers, and dehiscence resistant pods with gray pubescence and that are light gray, and the 100 seed weight is approximately $16 \mathrm{~g}$. It is resistant to lodging and reaches a height of around 80 to $115 \mathrm{~cm}$ in the South and 70 to $95 \mathrm{~cm}$ in the regions of Mato Grosso do Sul and Goiás.

It is resistant to reniform nematode (Rotylenchulus reniformis), moderately resistant to root-knot nematode (Meloidogyne incognita), and susceptible to Meloidogyne javanica species and to soybean cyst nematode (Heterodora glycines). It is resistant to stem canker (Diaporthe phaseolorum sp. meridionalis), brown stem rot (Cadophora gregata), and bacterial blight (Pseudomonas syringae pv glycinea). It is moderately resistant to frogeye leaf spot (Cercospora sojina), powdery mildew (Microsphaera diffusa), phytophthora root rot (Phytophthora sojae), and target leaf spot (Corynespora cassiicola) and susceptible to bacterial pustule (Xanthomonas axonopodis pv. glycines).
Table 3. Mean yield (MY) and relative yield (RY) of cultivar INT7100 IPRO compared to commercial controls in the 2015/2016, $2016 / 2017$, and 2017/2018 crop seasons in the 4 edaphic and climatic regions (ECR)

\begin{tabular}{|c|c|c|c|}
\hline $\mathrm{ECR}^{1}$ & Cultivar & MY $\left(\mathrm{kg} \mathrm{ha}^{-1}\right)$ & RY (\%) \\
\hline \multirow{3}{*}{103} & M6210IPRO & 3810 & 100 \\
\hline & DM 6563RSF IPRO & 4033 & 106 \\
\hline & INT7100 IPRO & 4297 & 113 \\
\hline \multirow{3}{*}{103} & M6210IPRO & 4313 & 113 \\
\hline & DM 6563RSF IPRO & 3831 & 100 \\
\hline & INT7100 IPRO & 4441 & 116 \\
\hline \multirow{3}{*}{202} & BMX POTÊNCIA RR & 3281 & 100 \\
\hline & BMX DESAFIO 8473 RSF RR & 3561 & 109 \\
\hline & INT7100 IPRO & 3599 & 110 \\
\hline \multirow{3}{*}{301} & BMX POTÊNCIA RR & 3473 & 102 \\
\hline & BMX DESAFIO 8473 RSF RR & 3403 & 100 \\
\hline & INT7100 IPRO & 3781 & 111 \\
\hline
\end{tabular}

\section{FOUNDATION SEED PRODUCTION}

The cultivar INT7100 IPRO was registered in the Brazilian Ministry of Agriculture (Ministério da Agricultura, Pecuária e Abastecimento - MAPA) on October 23, 2017 under number 37292. The seeds of the cultivar INT7100 IPRO are produced by Agropecuária Ipê, Tec Agro, Unigell Sementes, and Sementes Goiás. 
INT7100 IPRO - A soybean cultivar for an extensive growing area in the South and Cerrado in Brazil

\section{REFERENCES}

CONAB - Companhia Nacional de Abastecimento (2019) Acompanhamento da safra brasileira: grãos (Nono levantamento). Available at: <https:// www.conab.gov.br/component/k2/item/download/26760_3777945 9c5d79f63129c8c8c4d634103>. Accessed on June 27, 2019.

Uarrota VG, Segatto C, Voytena APL, Maraschin M, Avila LV, Kazama DCS,
Coelho CMM and Souza CA (2019) Metabolic fingerprinting of waterstressed soybean cultivars by gas chromatography, near-infrared and UV-visible spectroscopy combined with chemometrics. Journal of Agronomy and Crop Science 205: 141-156.

Sediyama T, Silva F and Borém A (2015) Soja: do plantio a colheita. Editora UFV, Viçosa, 333p. 